\title{
REFLEKS PAN KE DALAM BAHASA TABA: LANGKAH AWAL MENGUJI HIPOTESIS ADRIANI \& KRUYT (1914)
}

\author{
Burhanuddin \\ burhanuddin.fkip@unram.ac.id \\ Mahyuni \\ yonmahy@gmail.com \\ Sukri \\ sukrimuhammad75@yahoo.com \\ Universitas Mataram
}

\begin{abstract}
This study aims to explain Proto-Austronesian (PAN) reflexes in the Taba Language in North Maluku as a first step to test the hypotheses of Adriani \& Kruyt (1914). To explain the problem methodologically, a direct interview method was used in the field to Taba speakers. Interviews used 200 basic vocabulary and 500 cultural vocabulary words. The data analysis uses a topdown approach, a method of comparison and shared innovation according to those found in the principles of historical linguistic studies. Phonologically the Austronesian languages of South Halmahera, including Taba, according to Adriani \& Kruyt (1914) occur the final vowel removal and middle sound removal in the initial pressured word. The results of the identification turned out that not all PAN's final vocals experienced the disappearance of the Taba language, but experienced retention and innovation. Likewise in the middle position, there is very little PAN sound that is eliminated from the initial pressured word. Whether Adriani \& Kruyt's hypothesis (1914) applies to other Austronesian languages of South Halmahera that need to be studied further.
\end{abstract}

Keywords: historical linguistics, retention, innovation, phonological feature

\section{Pendahuluan}

Bahasa Taba (Tb) disebut juga bahasa Makian Timur, merupakan salah satu bahasa Austronesia yang digunakan di bagian timur Pulau Makian, Halmahera Selatan Provinsi Maluku Utara. Istilah bahasa Taba digunakan oleh Bowden (2001) dan Kamholz (2014), sedangkan bahasa Makian Timur digunakan Blust (2013) dan Lewis dkk (2016). Bahasa Taba juga digunakan di Pulau Kayoa (sebelah selatan Pulau Makian) dan tersebar di beberapa tempat di Pulau Halmahera dan Ternate. Oleh para ahli linguistik seperti Masinambow (1967), Blust (2013), Kamholz (2014) dan Lewis dkk (2016), isolek Taba di Pulau Kayoa dianggap sebagai dialek yang berbeda dengan di Pulau Makian. Oleh karena itu, Blust (2013) membagi bahasa Taba menjadi dua dialek, yaitu Dialek
Makian Timur (di Pulau Makian) dan Dialek Kayoa (di Pulau Kayoa).

Sebenarnya, di bagian barat Pulau Makian terdapat bahasa Makian Barat. Bahasa ini oleh sebagian besar ahli linguistik historis digolongkan ke dalam bahasa Non-Austronesia (NAN). Di wilayah Halmahera Selatan, wilayah bahasa antara bahasa-bahasa Austronesia dan Non-Austronesia tidak memiliki batas-batas geografis yang jelas karena keberagamannya. Oleh karena itulah, dalam tulisan ini digunakan istilah bahasa-bahasa Austronesia Halmahera Selatan, karena di wilayah ini terdapat penutur bahasa Non-Austronesia yang kompleks.

Secara linguistik historis, bahasa Taba digolongkan ke dalam Subkkelompok Halmahera Selatan bersama lima bahasa Austronesia 
lainnya, yaitu Buli (Bl), Maba (Mb), Sawai (Sw), Gebe (Gb), dan Gane (Gn) (Burhanuddin, Sumarlam \& Mahsun 2017 bandingkan dengan Blust 1978; Badan Bahasa 2008, dan Kamholz, 2014). Selanjutnya, Blust (1978), Kamholz (2014), dan Burhanuddin, Sumarlam \& Mahsun (2019) membagi bahasa-bahasa tersebut menjadi dua kelompok, yaitu Halmahera-TimurTengah-Selatan (HTTS) yang terdiri atas Buli, Maba, Sawai, dan Gebe) dan Halmahera Selatan-Selatan (HSS) yang terdiri atas Gane dan Taba. Menurut Blust (1978), Kelompok Halmahera Selatan terdiri atas Buli, Maba, Patani, Sawai, Gane, dan Taba, tetapi Badan Bahasa (2008), mengidentifikasi Maba dan Patani sebagai dua dialek dari satu bahasa, sedangkan Kamholz (2014) dan Burhanuddin (2017) menambahkan Gebe dalam kelompok ini.

Subkelompok Halmahera Selatan oleh sebagian besar linguistik historis termasuk dalam Kelompok Halmahera Selatan-Papua Barat (SHWG). Istilah Kelompok Halmahera Selatan-Papua Barat diperkenalkan oleh Adriani \& Kruyt (1914), dan didukung oleh Blust (1978, 1983/84, dan 1993). Keanggotaan kelompok ini terbentang dari barat mencakup semua bahasa Austronesia di Halmahera Selatan, Kepulauan Raja Ampat, Waigeo, Salawati, Misol, Pesisir Utara Kepala Burung, Pesisir Teluk Cenderawasi, Kepulauan Biak, Hingga Sarmi di paling timur pesisir utara, daratan Papua. Secara keseluruhan jumlah bahasa yang termasuk dalam kelompok ini diperkirakan antara 27-41 bahasa (Badan Bahasa 2008; Blust 2013; dan Lewis dkk. 2016), termasuk bahasa Taba.

Adriani \& Kruyt (1914), dengan menggunakan data terbatas dalam bahasa Buli dan Taba, menyimpulkan bahwa Kelompok Halmahera SelatanPapua Barat memiliki empat ciri, yaitu (1) hilangnya vokal akhir, (2) banyak kata menunjukkan penghilangan posisi tengah pada silabi yang diawali oleh tekanan, (3) kata ganti orang ketiga jamak si dijadikan sebagai penanda nomina jamak, dan (4) menggunakan genetif terbalik (urutan pemiliktermilik).

Berdasarkan uraian di atas, tulisan ini bermaksud menjelaskan dua hal, yaitu bentuk inovasi internal aspek fonologi dan aspek leksikal yang terjadi dalam bahasa Taba, dari perspekstif linguistik historis. Studi ini bersifat linguistik historis karena pengidentifikasian terhadap kedua aspek tersebut dilakukan melalui perbandingan unsur kebahasaan yang terdapat dalam bahasa Taba dengan lima bahasa Halmahera Selatan lain yang sekerabat dengannya.

\section{Tinjauan Pustaka}

Ada beberapa studi yang relevan dengan studi ini baik dari aspek tujuan maupun objek yang dikaji. Pertama, Adriani \& Kruyt (1914) menjelaskan ciri-ciri Subrumpun Halmahera Selatan-Papua (HSPB). Menurutnya, Subrumpun HSPB memiliki empat ciri, yaitu (1) hilangnya vokal akhir; (2) banyak kata menunjukkan penghilangan posisi tengah pada silabe yang diawali oleh tekanan; (3) kata ganti orang ketiga jamak si dijadikan sebagai penanda nomina jamak; dan (4) menggunakan genetif terbalik (urutan pemilik-termilik). Kedua, Kamholz (2014) menjelaskan fonem ProtoSubrumpun HSPB dan mengelompokkan bahasa-bahasa SHWG dalam beberapa kelompok. Ketiga, Jamulia (2016) menjelaskan hubungan budaya komunitaskomunitas Halmahera Selatan dari perspektif budaya dan bahasa, tetapi tidak berdasarkan kerangka kerja dalam studi linguistik historis yang sesungguhnya.

Ketiga, Burhanuddin, Sumarlam, Mahsun, \& Fernandez (2016) menjelaskan tentang urgensi bahasabahasa Halmahera Selatan perlu dikaji secara linguistik historis. Keempat, studi Burhanuddin, Sumarlam, Fernandez, \& Mahsun (2017) berjudul 
Kekhasan Aspek Fonologi dan Leksikal Bahasa Sawai di Maluku Utara Perspektif Linguistik Historis. Studi ini menjelaskan tentang perbedaan bahasa Sawai dengan bahasa Halmahera Selatan lainnya (Maba, Taba, Buli, Gane, dan Gebe) secara linguistik baik secara fonologis maupun leksikon. Secara metodolologis, penjelasan terhadap hal tersebut dilakukan dengan cara membandingkan bahasa Sawai dengan lima bahasa Halmahera Selatan lainnya. Kelima, studi Burhanuddin, Ahmadi \& Yulida (2018) tentang Refleks Proto-Austronesia (PAN) ke dalam Bahasa Buli di Maluku Utara. Studi ini bertujuan menjelaskan tentang pola perubahan PAN ke dalam bahasa Buli tanpa mengaitkan dengan hipotesis yang dibuat Adriani \& Kruyt (1914), meskipun bahasa Buli merupakan anggota Subrumpun Halmahera Selatan-Papua Barat. Keenam, studi Burhanuddin (2018) yang berjudul Internal Innovation of Taba in Northern Maluku Historical Linguistics Perspective. Studi ini mirip dengan studi yang dilakukan Burhanuddin, Sumarlam, Fernandez \& Mahsun (2017), hanya saja objek kajiannya bahasa Sawai. Keenam, Burhanuddin, Mahyuni \& Sukri (2019) tentang tanggapan secara umum tentang hipotesis Adriani \& Kruyt (1914). Studi ini melibatkan enam bahasa Halmahera Selatan, yaitu Maba, Buli, Sawai, Gane, Taba, dan Gebe. Namun, studi yang secara spesifik menjelaskan ihwal hipotesis tersebut dalam bahasa Taba belum dijelaskan.

\section{Metode Penelitian}

Data kebahasaan dalam bahasa Taba dan lima bahasa Halmahera Selatan lainnya dikumpulkan menggunakan metode wawancara berupa 200 kosa kata dasar dan 1000 kosa kata dasar, teknik catat dan rekam (Mahsun, 2013). Metode dokumentasi digunakan untuk mengumpulkan Proto-Austronesia (PAN) yang direkonstruksi Blust \&
Trussel (2014) dalam Blust's Austronesian Comparative Dictionary. Lalu, data dianalisis menggunakan pendekatan top-down, dengan melihat perubahan bunyi dari PAN dan PHS ke dalam bahasa-bahasa Halmahera Selatan dengan metode komparatif, teknik inovasi bersama.

\section{REFLEKS PAN DAN RESPONS TERHADAP HIPOTESIS ADRIANI \& KRUYT (1914)}

Sesuai tujuannya, pada bagian ini dijelaskan refleks PAN ke dalam bahasa Taba yang terurai pada subbagian pertama. Hasil identifikasi tersebut kemudian dibandingkan dengan hipotesis Hipotesis Adriani \& Kruyt (1914) yang diuraikan pada subbagian kedua.

\section{Refleks PAN ke Taba}

Berdasarkan data yang dikumpulkan, dalam bahasa Taba, ditemukan pola refleks PAN ke dalam Taba.

$* p$

Hasil identifikasi menunjukkan PAN *p pada posisi awal mengalami perubahan secara teratur menjadi $h$, sedangkan menjadi $f$ dan $s$ terjadi secara tidak teratur. Hanya sedikit data ditemukan *p mengalami retensi, artinya terjadi secara tidak teratur. Pada posisi tengah, * $\mathrm{p}$ dalam bahasa Taba mengalami retensi dan inovasi $(h$ dan b) masing-masing terjadi secara tidak teratur. jika data diperluas, perubahan menjadi $\mathrm{h}$ dimungkinkan terjadi secara teratur. Adapun pada posisi akhir hanya mengalami inovasi secara tidak teratur menjadi $q$.

Data (1a)

PAN Taba

*paniki (kelelawar) nhik *p>h/\#-

*penu (penyu/kura-kura) hen

*paqiC (pahit) mhait

*penuq (penuh) mehon

Dalam Burhanuddin, Sumarlam, \& Mahsun (2019) dinyatakan bahwa PAN *paniki 'kelelawar'> *panik> *fanik (*p 
$>$ f teratur dalam bahasa-bahasa Halmahera Selatan) > $>$ fnik $>$ *hnik (perubahan *p atau ${ }^{*} \mathrm{f}$ menjadi: $\mathrm{h}$ teratur dalam bahasa Taba) > Taba: nhik (metatesis). PAN *penu (penyu) $>$ *fenu $>$ *henu> *henu> Taba: hen. PAN *paqiC (pahit)> *paqit> *pait> *fait> *hait> Taba: mhait. Adapun PAN *penuq 'penuh' $>$ *fenuq $>$ *henuq $>$ *henu $>$ *hen $>{ }^{*}$ mhen $>{ }^{*}$ mhen $>$ *mehen $>$ Taba: mehon (disimilasi).

(1b)

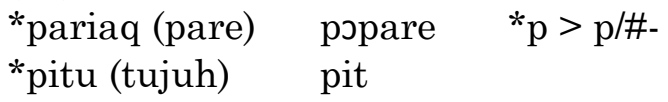

(1c)

*paRi (pari) fa $\quad * p>f / \#-$

*pija (berapa) fiso

(1d)

*qatep (atap) yotas *p $>$ s/\#-

(1e)

*sepat (empat) phot *p $>$ p/\#-\#

*kapua (kapas) kailupa

(1f)

*tipis (tipis) mnihis $\quad * \mathrm{p}>\mathrm{h} / \# \#$

*sipan (lipan) lihan

(1g)

*qasep 'asap' neasıq *p $>$ q/-\#

(1h)

*tiup 'tiup' uho $\quad * p>q /$-\#

${ }^{*} t$

Data (2a)-(2f), apabila dicermati, PAN *t pada posisi awal mengalami retensi dan inovasi masing-masing tidak teratur menjadi: $ø$ dan $n$. Pada posisi antarvokal, *t mengalami retensi secara teratur, menghilang secara tidak teratur. Begitu juga pada posisi akhir mengalami retensi secara teratur.

*takut (takut) kiu $\quad *$ t $>\varnothing / \#-$

*tiyup (tiup) uho

(2b)

*tipis 'tipis' mnihis $\mathrm{t}>\mathrm{n} / \#$ -

(2c)

*tilen (telan) tolan $t>t / \#-$

(2d)

*qatep (atap) yotas $\quad \mathrm{t}>\mathrm{t} / \#$-\#

*rantay (kalung) rante *qetut (kentut) citsi

*kuta(n,n)a (tanya) kutan

*pitu (tujuh) pit

(2e)

*Niteq 'aren, enau' nou *t $>$ ø/\#-\#

(2f)

*dakit (rakit) dat *t $>$ t / \#

*lumut (lumut) lumut

*qetut (kentut) citji

${ }^{*} C$

Data (3a)-(3f) memperlihatkan bahwa PAN ${ }^{*} \mathrm{C}$ mengalami retensi dan inovasi masing-masing terjadi secara tidak teratur. Pada posisi tengah mengalami inovasi menjadi $t$ secara teratur dan menjadi: $y$ secara tidak teratur. Adapun pada posisi akhir mengalami perubahan secara tidak teratur menjadi: $s$ dan $ø$. Perubahan ${ }^{*} \mathrm{C}$ menjadi: $t$ pada posisi akhir dimungkinkan terjadi secara teratur jika datanya diperluas.

(3a)

${ }^{*}$ CawiN (tahun) taun $\quad{ }^{*} \mathrm{C}>\mathrm{t} / \#$ -

(3b)

${ }^{*}$ Caki (berak/tahi) cioi $\quad{ }^{*} \mathrm{C}>\mathrm{c} / \#-$

(3c)

*kuCu (kutu) kut $\quad{ }^{*} \mathrm{C}>\mathrm{t} / \#$-\#

*maCa (mata) mts

*aCay (mati) mot

*qiCeluR (telur) tolo

(3d)

*aCas (atas) yase $\quad{ }^{*} \mathrm{C}>\mathrm{y} / \#-\#$

(3e)

*likaC (kilat) lilas $\quad{ }^{*} \mathrm{C}>\mathrm{s} /=$

(3f)

*kuliC (kulit) liks $\quad{ }^{*} \mathrm{C}>\varnothing /-\#$

(3g)

*langiC (langit) langit $\quad * \mathrm{C}>\mathrm{t} /$-\#

*paqiC (pahit) mhait

${ }^{*} c$

PAN ${ }^{*} \mathrm{c}$ mengalami perubahan menjadi $s$ dan terjadi secara tidak teratur dalam bahasa Taba, misalnya *pica 'kapan' menjadi Taba: paiso.

$* k$

PAN * $\mathrm{k}$ pada posisi awal mengalami retensi secara teratur. Selain itu, pada 
posisi awal mengalami penghilangan secara teratur dan menjadi $l$ secara tidak teratur. Pada posisi tengah, ${ }^{*} k$ mengalami retensi dan penghilangan secara teratur, sedangkan menjadi: $y$ dan $l$ terjadi secara tidak teratur. Adapun pada posisi akhir PAN ${ }^{*} \mathrm{k}$ mengalami retensi secara tidak teratur.

(4a)

$\begin{array}{lll}\text { *kutana (tanya) } & \text { kutan } & * \mathrm{k}>\mathrm{k} / \#- \\ \text { *kuliC (kulit) } & \text { likə } & \\ \text { *kamay (tangan) } & \text { kəm } \\ \text { *kapua (kapas) } & \text { kəpas }\end{array}$

(4b)

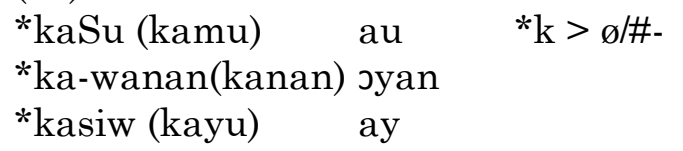

(4c)

*takut (takut) kiu

*siku (siku) kuo

(4d)

*wakaR (akar) wowo *k $>$ ø/\#-\#

*dakit (rakit) dat

${ }^{*}$ Caki (tahi/berak) cioi

(4e)

*Sikan (ikan) iyan *k $>$ y/\#-\#

(4f)

*likaC (kilat) lilas $\quad * k>1 / \#$-\#

$(4 \mathrm{~g})$

*manuk (ayam) manic *k $>\mathrm{k} /$-\#

${ }^{*} q$

Pada posisi awal PAN *q mengalami penghilangan dan menjadi: $y$ secara teratur. pada posisi awal juga berubah menjadi $n, w$, dan $t$ secara tidak teratur. Pada posisi dan akhir, ${ }^{*} \mathrm{q}$ juga mengalami penghilangan secara teratur. Pada posisi akhir, mengalami retensi secara tidak teratur.

(5a)

*qasep (asap) neasoq $\quad{ }^{*} q>$ ny/\#-

(5b)

*qatep (atap) yotas $\quad * q>y / \#-$

*qasiRa (garam) yasin

*qasin (asin) miyasin

$(5 c)$

*qudan (udang) ulan $\quad * q>ø / \#-$ $\begin{array}{ll}\text { *qutan (hutang) } & \text { utan } \\ \text { *qasawa (kawin) } & \text { isow } \\ \text { *qatimun (timun) } & \text { timu }\end{array}$

(5d)

*qiSu (hiu) woi $\quad$ *q $>$ w/\#-

(5e)

*lanaw (lalat) plan *q $>$ t/\#-

(5f)

*Caqu (tahu) unak *q $>$ o/\#-\#

*liseqeS (telur kutu) los

*paqiC (pahit) mhait

(5g)

*daraq (darah) loq $\quad$ *q $>$ q/-\#

(5h)

*Rumaq (rumah) um $\quad$ *q $>\varnothing /$-\#

*pariaq (pare) popare

*penuq (penyu) hen

*salaq (salah) sol

$* b$

Pada posisi awal, PAN *b mengalami retensi dan inovasi (menjadi: $p$ ) secara tidak teratur, yaitu PAN *buna 'bunga' dan *bubu 'cucu' > Taba: buna dan buq (PAN *b > b/\#-) serta PAN *banun 'bangun' > Taba: panin $(\mathrm{PAN} * \mathrm{~b}>\mathrm{p} / \#-$. Begitu juga pada posisi tengah, menghilang secara tidak teratur, yaitu PAN *buna 'bunga' > Taba: buna.

${ }^{*} d d a n * z$

Bunyi *d mengalami retensi dan inovasi (menjadi: $l$ ) secara tidak teratur pada posisi awal, yaitu PAN *dakit 'rakit' > Taba: dat serta *deneR 'dengar' $>$ Taba: longa. Adapun PAN *z pada posisi tengah mengalami perubahan menjadi: $l$ secara tidak teratur, hanya ditemukan pada PAN *maquzan 'hujan' > Taba: ulan.

$*_{j}$ dan ${ }^{*} g$

Pada posisi tengah PAN *j mengalami perubahan, menjadi: $s$ (PAN *pija 'berapa' > Taba: fiso) dan ø (PAN *ulej > Taba: let), serta menjadi: $t$ (PAN *ijuSung 'hidung' > Taba: hungo) pada posisi akhir masing-masing terjadi secara tidak teratur. Adapun pada posisi awal, PAN * ${ }^{*}$ mengalami retensi secara tidak teratur, misalnya *garut 
'garuk' dan *jagah 'jaga'> gag dan jagajaga.

*m dan *n

PAN ${ }^{*} \mathrm{~m}$ pada posisi tengah dan akhir masing-masing mengalami retensi secara teratur, sedangkan pada posisi awal mengalami retensi secara tidak teratur.

(6a)

*manuk (ayam)

*maCa (mata)

manic $* \mathrm{~m}>\mathrm{m} / \#$ -

mts

(6b)

*ami (kami)

am $\quad * m>m / \#-\#$

*Rumah (rumah) um

*miqmiq (air kencing) maimi

*lumut (lumut) lumut

*qatimun (timun) timu

*lima (lima) lima

(6c)

*inum (minum) imin $\quad * \mathrm{~m}>\mathrm{m} /$-\#

*tanam (tanam) tonam

*enem (enam) ponam

Pada posisi tengah dan akhir, PAN *n masing-masing mengalami retensi secara teratur. Adapun pada posisi awal menghilang secara tidak teratur.

(7a)

*nia (dia/ia) i $\quad * n>\varnothing / \#-$

(7b)

*manuk (ayam) manic *n>n/t

*tanem (tanam) tonam

*rantay (kalung) rante

* paniki (kelelawar) nhik

*enem (enam) ponam

dan sebagainya

(7c)

*Sipan (lipan) lihan *n $>$ n/-\#

*banun (bangun) panin

$* N$

Pada posisi awal, PAN ${ }^{*} \mathrm{~N}$ menjadi: $m$ dan $n$ secara tidak teratur, sedangkan pada posisi tengah menjadi: $n, d$, dan $ø$, masing-masing secara tidak teratur. Adapun pada posisi akhir mengalami perubahan menjadi: $n$ secara teratur.

(8a)

NiSawa (napas) manəwวq * $\mathrm{N}>\mathrm{m} / \#$ - (8b)

Niteq (aren/enau) nou $\quad * \mathrm{~N}>\mathrm{n} / \#-$

(8c)

*Nipis (tipis) mnihis $\quad{ }^{*} \mathrm{~N}>\mathrm{n} / \# \#$

(8d)

${ }^{*}$ waNu (madu) madu $\quad{ }^{\mathrm{N}}>\mathrm{d} / \#-\#$

(8e)

*qaNiCu 'setan' guwo * $\mathrm{N}>$ ø/\#-\#

(8f)

*maquzaN (hujan) ulan $\quad * \mathrm{~N}>\mathrm{n} /$-\#

*kawanaN (kanan) oyan

*CawiN (tahun) taun

*qasiN (asin) miyasin

*n dan *n

Pada posisi awal dan tengah, PAN ${ }^{*}$ n berubah menjadi: $n$, secara tidak teratur.

(9a)

$*^{*}$ namuR (embun) nomi $\quad *_{n}>n / \#-$ *niuR (kelapa) niwi $\quad * n>n / \#$.

(9b)

*penuq (penyu) hen $\quad *_{n}>$ n/\#-\#

*kutana (tanya) kutan

PAN * $\eta$ pada posisi tengah masingmasing mengalami retensi dan inovasi (menjadi: $m$ dan $\varnothing$ ) secara tidak teratur. Adapun pada posisi akhir mengalami retensi secara teratur dan menjadi: $n$ secara tidak teratur.

(10a)

*bubunan (bubungan) punan * $\eta>\eta / \#-\#$

*lanaw (lalat) plan

(10b)

*balinbin (belimbing) balimbin * $n>m / \#-\#$

(10c)

*banban (kupu-kupu) baban *n> ø/\#-\#

(10d)

*banban (kupu-kupu) baban *n> $/$-\#

*qudan (udang) ulan

*tepen (mencicipi) tohan

*ulan (ulang) mulan

dan sebagainya

(10e)

*balinbin (belimbing) balimbin * $n>n /-\#$

*s dan ${ }^{*} S$

Pada posisi awal dan akkhir PAN * $\mathrm{S}$ mengalami retensi secara tidak teratur. 
Adapun pada posisi tengah dan akhir mengalami retensi secara teratur.

(11a)

$\begin{array}{lll}\text { *salaq (salah) } & \text { sol } & \text { *s }>\text { s/\#- } \\ \text { *siwa (sembilan) } & \text { siwo } & \\ \text { (11b) } & & \\ \text { *qasawa (kawin) } & \text { isow } & * \text { *s }>\text { s/\#-\# } \\ \text { *qasin (asin) } & \text { miyasin } & \\ \text { *isa 'satu' } & \text { iso } & \\ \text { *qasiRa (garam) } & \text { yasin } & \\ \text { (11c) } & & \\ \text { *dalis (halus) } & \text { alus } & * \mathrm{~s}>\mathrm{s} / \text {-\# } \\ \text { *i-atas (di atas) } & \text { yase } & \end{array}$

PAN *S masing-masing menghilang dan menjadi: $l$ pada posisi awal secara tidak teratur, sedangkan pada posisi tengah menghilang secara teratur.

(12a)

\begin{tabular}{|c|c|c|}
\hline \multirow{2}{*}{$\begin{array}{l}\text { *Sipan (lipan) } \\
(12 \mathrm{~b})\end{array}$} & \multirow[t]{2}{*}{ lihan } & \multirow[t]{2}{*}{$* \mathrm{~S}>1 / \#-$} \\
\hline & & \\
\hline *Sepat (empat) & phot & ${ }^{*} \mathrm{~S}>\varnothing / \#-$ \\
\hline *Sikan (ikan) & iyan & \\
\hline$(12 c)$ & & \\
\hline *duSa (dua) & plu & ${ }^{*} \mathrm{~S}>\varnothing / \#-\#$ \\
\hline *kaSu (kamu) & $\mathrm{au}$ & \\
\hline *qiSu (hiu) & woi & \\
\hline *kaSiw (pohon) & ai & \\
\hline
\end{tabular}

PAN *h menghilang secara tidak teratur, misalnya ${ }^{*} \mathrm{~h}>$ zero/ $\#=136$. Pada posisi awal dan tengah, *1 mengalami retensi secara teratur. PAN ${ }^{*} r$ menghilang secara tidak teratur pada posisi tengah, dan mengalami retensi secara tidak teratur pada posisi awal. PAN * $\mathrm{R}$ menghilang pada posisi tengah dan akhir secara teratur. Adapun PAN ${ }^{*} \mathrm{~W}$ mengalami retensi dan inovasi (menjadi: $\mathrm{m}$ ) pada posisi awal secara tidak teratur. Adapun pada posisi tengah menghilang secara tidak teratur.

(13a)

$\begin{array}{lll}\text { *laniC (langit) } & \text { lanit } & \text { *l } 1>1 / \#- \\ \text { *lahut (laut) } & \text { wolat } & \\ \text { *lumut (lumut) } & \text { lumut } & \\ \text { dan sebagainya } & & \end{array}$

(13c)

*ulej (cacing) let $\quad * 1>1 / \#-\#$
*qiCeluR (telur) tolo

*balinbin (belimbing) balimbin

*salaq (salah) sol

dan sebagainya

(14a)

*rantay (kalung) rante $\quad{ }^{*} r>r / \#-$

(14b)

$*^{*}$ garut (garuk) gag $\quad{ }^{*} \mathrm{r}>\varnothing / \# \#$

(14c)

${ }^{*}$ kersiq (bersih) beresi $\quad{ }^{*} \mathrm{r}>\mathrm{r} / \#-\#$

(15a)

*baReq (bengkak) mbos $\quad * \mathrm{R}>\varnothing / \#-\#$

*daRaq (darah) loq

(15b)

*waSiR (air) wәya $\quad * \mathrm{R}>\varnothing /$ \#

*wakaR (akar) wowo

*nyiuR (kelapa) niwi

*deneR (dengar) lona

dan sebagainya.

(16a)

${ }^{*}$ waSiR (air) woya $\quad{ }^{*}$ w $>$ w/\#-

*wakaR (akar) wowo

(16b)

*waNu (madu) madu $\quad{ }^{*}$ w $>$ m/\#-

(16c)

*kawanaN (kanan) oyan $\quad{ }^{*} \mathrm{w}>$ ø/\#-\#

${ }^{*} a$

Pada posisi awal, PAN *a mengalami retensi dan menghilang secara tidak teratur. Pada silabe penultima masing-masing mengalami retensi dan inovasi (menjadi: o) secara teratur, sedangkan menjadi: $i$ terjadi tidak teratur. Pada silabe ultima, PAN *a mengalami retensi secara teratur, menjadi: $o$ secara tidak teratur. Adapun pada posisi akhir menghilang dan menjadi: o secara teratur, serta mengalami retensi secara tidak teratur.

(17a)

*aku (saya/aku) yak *a >a/\#-

$(17 b)$

*apuq (anaknya cucu) bu *a $>\varnothing / \#-$

(17c)

*likaC (kilat) lilas *a $>$ a/\#K-

*CawiN (tahun) taun

*tanem (tanam) tonam

*dakit (rakit) dat

dan sebagainya. 
$(17 d)$

*maCa (mata) mto *a $>$ o/\#K

*aCay (mati) mot

*Nisawaq (napas) manəwoq

*kamay (tangan) kəmo

dan sebagainya.

(17e)

*qasawa (kawin) isow *a $>$ i/\#K-

(17f)

*Sepat (empat) phot *a $>$ o/-K\#

(17g)

*qudan (udang) ulan

*aCas (atas) yase

*qutan (hutang) uran

dan sebagainya.

(17h)

*buna (bunga) buna *a $>$ a/-\#

(17i)

*pica (kapan) paiss *a $>\mathrm{o} /$ \#

*maCa (mata) mts

*isa 'satu' pso

*pija 'berapa' fiso

dan sebagainya.

(17j)

*lima (lima) plim *a $>\varnothing /-\#$

*qasawa (kawin) isow

*kutana (tanya) kutan

dan sebagainya.

*e

PAN *e mengalami retensi dan inovasi (menjadi: $i$ dan $ø$ ) secara tidak teratur pada silabe penultima, serta menjadi: o terjadi secara teratur. Adapun pada silabe ultima berubah menjadi: a secara teratur, sedangkan mengalami retensi dan inovasi (menjadi: $o$ ) secara tidak teratur.

(18a)

*penuq (penuh) mehon *e > e/\#K-

(18b)

*qetut (kentut) citji $\quad{ }^{*} \mathrm{e}>\mathrm{i} / \# \mathrm{~K}$ -

(18c)

*enem (enam) ponam *e > o/\#K-

*deneR (dengar) lona

*qiCeluR (telur) tolo

(18d)
*Sepat (empat) phot $\quad * \mathrm{e}>ø / \# \mathrm{~K}$ -

(18e)

*qasep (atap) neasoq *e $>$ o/-K\#

*tanem (tanam) tonam

(18f)

*qatep (atap) yotas *e $>$ a/-K\#

*deneR (dengar) lona

*enem 'enam' ponam

$(18 \mathrm{~g})$

*ulej (cacing) let $\quad * \mathrm{e}>\mathrm{e} /-\mathrm{K \#}$

$*_{i}$

Pada posisi awal, PAN *i menghilang secara teratur dan mengalami retensi secara tidak teratur. Pada silabe penultima, PAN *i mengalami retensi secara teratur dan menjadi: o secara tidak teratur. Pada silabe ultima dan posisi akhir juga mengalami retensi secara teratur, sedangkan pada posisi menjadi: $e$ dan $\varnothing$ pada posisi akhir terjadi secara tidak teratur.

(19a)

*inum (minum) imin $\quad * i>i / \#-$

(19b)

*qasiRa (garam) yasin $\quad * i>\varnothing / \#-$

*ijuSun (hidung) hun

*ini (ini) ine

*isa (satu) pso

(19c)

*nia (dia/ia) i

*Sikan (ikan) iyan

*pica 'kapan' paiso

*likaC 'kilat' lilas

dan sebagainya.

(19d)

*gilin (giling) golinan $\quad *_{\mathrm{i}}>\mathrm{o} / \# \mathrm{~K}$ -

(19e)

*laniC (langit') lanit $\quad * \mathrm{i}>\mathrm{i} / \mathrm{-K \#}$

*tipis (tipis) mnihis

*miqmiq (air kencing) maimi

*labaw (tikus) los

dan sebagainya.

(19f)

*ini (ini)

inc $\quad *_{\mathrm{i}}>\mathrm{e} / \mathrm{- \#}$

(19g)

*ami (kami) am $\quad * i>ø /=\#$ 
*paniki (kelelawar) nhik

(19h)

$\begin{array}{lll}\text { *gusi (gusi) } & \text { gusi } & \\ \text { *Suanji (janji) } & \text { janji } & \text { i } \mathrm{i}>\mathrm{i} / \text {-\# } \\ \text { *adi (yang) } & \text { idia } & \\ { }^{*} \text { Caqi (tahi/berak) ciji } & \end{array}$

${ }^{*} u$

Pada silabi penultima dan akhir, PAN *u mengalami retensi secara teratur. Selain mengalami retensi, PAN *u mengalami inovasi menjadi: $i$ secara teratur dan menghilang secara tidak teratur pada silabe penultima. Pada posisi akhir juga menghilang secara teratur, sedangkan pada silabe ultima mengalami retensi dan menghilang secara tidak teratur.

(20a)

$\begin{array}{lll}\text { *buna (bunga) } & \text { buna } & \text { *u }>\mathrm{u} / \# \mathrm{~K}- \\ \text { *duSa (dua) } & \text { pso } & \\ \text { *kutu (kutu) } & \text { kut } & \\ \text { *lusun (lesung) } & \text { lusin } & \\ \text { dan sebagainya. } & \end{array}$

(20b)

*inum (minum) imin $\quad * u>i / \# K-$

*gusi (gusi) ngisi

*qasawa (kawin) isow

*lumut (lumut) lumut,

dan sebagainya.

(20c)

*ulej (cacing) let *u $>$ ø/\#K-

*ma-quzaN (hujan) ulan

(20d)

*penyur

(20e)

*ikuR (ekor) kaku *u $>\mathrm{u} / \mathrm{K}$ K\#

(20f)

$\begin{array}{ll}\text { *kaSu (kamu) } & \text { au } \\ \text { *susu (susu) } & \text { susu } \\ \text { *bubu (cucu) } & \text { buq } \\ \text { *waNu (madu) } & \text { madu } \\ \text { dan sebagainya. } & \end{array}$

(20g)

*kutu (kutu) kut *u $>$ ø/-\#

*aku (saya/aku) yak

*telu (telu) ptol

*walu (delapan) powal

dan sebagainya. *ay dan *aw

PAN *ay pada posisi akhir mengalami inovasi secara tidak teratur menjadi e, o, dan ø, sedangkan *aw menghilang secara tidak teratur.

(21a)

*aCay (mati) mot *ay $>\varnothing /$-\#

(21b)

*kulay (cacing) let *ay $>$ e/-\#

*rantay (kalung) rante

(21c)

*kamay (tangan) kom $\quad$ *ay $>$ o/\#

(22)

*lanaw (lalat) plan *aw $>\varnothing /-\#$

Hipotesis Adriany \& Kruyt (1914) dalam Cerminan Bahasa Taba

Dua dari empat hipotesis mengenai ciri Subrumpun Halmahera SelatanPapua Barat (HSPB) (termasuk bahasa Taba) bersifat fonologis. Yaitu, bunyi vocal pada posisi akhir menghilang secara teratur dan vokal menghilang pada kata yang bertekanan pada silabe awal. Mencermati refleks vocal PAN ke dalam bahasa Taba dapat dijelaskan sebagai berikut.

Mengenai hilangnya bunyi vokal pada posisi akhir. Jika dicermati refleks vokal: $a$ dapat dikatakan bahwa bunyi tersebut tidak hanya menghilang secara teratur (data 17j)) tetapi juga mengalami perubahan secara teratur menjadi: o (perhatikan data (17i)). Selain itu, terdapat retensi PAN *a dalam bahasa Taba bersifat tidak teratur (lihat data (17h)). Artinya, untuk vokal: a, hipotesis Adriani dan Kruyt (1914) tidak mutlak benar. Untuk vokal *e, sejauh belum ditemukan etimon PAN yang berada pada posisi akhir sehingga untuk menjelaskan perihal keterperubahan vokal *e dalam bahasa Taba tidak dapat dilakukan. Vokal *i, justru mengalami retensi secara teratur pada posisi akhir (lihat data (19h)) dan belum ditemukan penghilangan secara teratur pada posisi akhri (hanya ditemukan dua data, (lihat data (19g). Adapun vokal ${ }^{*} \mathrm{u}$, tidak hanya terjadi 
penghilangan secara teratur, tetapi mengalami retensi secara teratur (lihat data $20 \mathrm{f}$ dan 20g) sehingga hipotesis Adriani dan Kruyt (1914) perlu ditinjau (bandingkan dengan Burhanuddin, Mahyuni, dan Sukri, 2019).

Mengenai penghilangan vokal pada silabe yang bertekanan awal, dapat dikemukakan bahwa data yang memperlihatkan hal tersebut masih terbatas, yaitu PAN *maCay 'mata' > Taba: mtod. Data tersebut memperlihatkan terjadi penghilangan *a pada silabe penultima. Sebenarnya, penghilangan sejenis tersebut ditemukan pada beberapa data lain, tetapi kata-kata tersebut tidak bertekanan seperti yang dimaksud Adriani dan Kruyt (1914).

Mencermati gejala keterperubahan bunyi dalam bahasa Taba (salah satu anggota Subrumpun Halmahera Selatan-Papua Barat), hipotesis Adriani dan Kruyt (1914) dapat dikatakan belum dapat diterima seutuhanya. Artinya, hipotesis tersebut perlu direvisi dan diperluas. Sebab, vokal PAN pada posisi akhir tidak hanya menghilang tetapi juga dipelihara dan mengalami perubahan. Begitu juga dengan hipotesis kedua, ciri tersebut untuk sementara dapat dikatakan bukanlah ciri yang dominan bahasabahasa Subrumpun HSPB karena gejalah tersebut tidak terjadi dalam bahasa Taba yang merupakan salah satu anggota Subrumpun HSPB.

\section{SIMPULAN}

Mencermati refleks PAN ke dalam Bahasa Taba, dapat dikemukakan bahwa keterperubahan tersebut ada yang bersifat teratur dan tidak teratur. Perubahan yang bersifat teratur dan tidak teratur tersebut ada yang bersifat retensi dan inovasi. Perubahan yang berupa retensi dan inovasi tersebut terjadi pada hamper semua fonem PAN ke dalam bahasa Taba. Jika dikaitkan dengan hipotesis Adriani dan Kruyt (1914), bahwa bahasa-bahasa Subrumpun Halmahera Selatan-Papua
Barat mengalami penghilangan vokal pada posisi akhir tidak mutlak sifatnya. Sebab, vokal akhir bahasa Taba (salah satu anggota Subrumpun HSBP) tidak hanya menghilang tetapi mengalami retensi (dipelihara/tidak berubah) dan inovasi (perubahan) secara teratur. Begitu juga dengan penghilangan vocal pada silabe bertekanan awal, terbatas sifatnya. Kaitan dengan hal tersebut, perlu dilakukan studi pada bahasabahasa anggota HSPB yang lain yang untuk membuktikan apakah gejala yang dihipotesis Adriani dan Kruyt (1914) tersebut dominan terjadi atau tidak.

\section{UCAPAN TERIMAKASIH}

Artikel ini disusun berdasarkan hasil penelitian lapangan yang didanai oleh Kementerian Riset, Teknologi, dan Pendidikan Tinggi Republik Indonesia melalui Penelitian Kompetitif Nasional Skema Riset Dasar selama 2019-2021.

\section{DAFTAR PUSTAKA}

Adriani, N \& Kruyt, AC. 1914. De Bare'esprekende Toradjas van MiddenCelebes. Batavia: Landsdrukkerij

Badan Bahasa. 2014. Bahasa dan Peta Bahasa di Indonesia. Jakarta: Departemen Pendidikan Nasional.

Blust, Robert A. 1978. "Eastern MalayoPolynesian: A Subgrouping Argument" dalam SA Wurm and Lois Carrington (eds). Second International Conference on Austronesian Linguistics Proceedings. Pacific Linguistics Series C (61): 181-234

Blust, Robert A. 1983-84. "More on the Position of the Languages of Eastern Indonesia”. Oceanic Linguistics Journal, (22-23): 1-28

Blust, Robert A. 1993. "Central and Central-Eastern Malayo-Polynesian". Oceanic Linguistics Journal, (32): 241293

Blust, Robert A. 2013. The Austronesian Languages. Revision Edition. Canberra: Pacific Linguistics

Blust, Robert A. \& S. Trussel. 2014. Austronesian Comparative Dictionary. 
Available online at www.trussel2.com/ ACD

Bowden, J. 2001. Taba: Descripstions of a South Halmahera Language. Canberra: Pacific Linguistics

Burhanuddin, Sumarlam, Mahsun, \& Fernandez. 2016. "Urgensi Studi Linguistik Historis Bahasa Subrumpun Halmahera Selatan-Papua Barat”. Proceeding International Seminar Prasasti III, Current Research in Linguistics: 184-189

Burhanuddin, Sumarlam, \& Mahsun. 2017. "Kedudukan Bahasa Gebe di Halmahera Tengah Maluku Utara: Studi Pendahuluan dari Aspek Linguistik Historis”. Jurnal Arkhais, 8 (1)

Burhanuddin, Ahmadi, \& Yulida. 2018. Refleks PAN to Buli in North Maluku. In Advances in Social Science, Education and Humanities Research (ASSEHR), volume 148, Proceedings of The Sixth International Conference in Language and Arts (ICLA-6):113-121.

Burhanuddin, Sumarlam, Fernandez, \& Mahsun (2017). "Kekhasan Aspek Fonologi dan Leksikal Bahasa Sawai di Maluku Utara Perspektif Linguistik Historis" dalam Prosiding Seminar Nasional Kajian Mutakhir Bahasa, Sastra, dan Budaya Daerah untuk Membangun Kebhinekatunggalikaan Negara Kesatuan Republik Indonesia (1): $78-85$

Burhanuddin. 2018. "Internal Innovation of Taba in Northern Maluku Historical Linguistics Perspective". Jurnal Humanus, 16 (2): 239-247
Burhanuddin, Mahyuni, \& Sukri. 2019. "Response to Adriani and Kruyt (1914): About South Halmahera-West New Guinea Feature". In Advances in Social Science, Education and Humanities Research (ASSEHR) 338: Proceding of The $5^{\text {th }}$ International Seminar Prasasti

Burhanuddin, Sumarlam, \& Mahsun. 2019. "The Complexity of Phonological Change in South Halmahera Languages". Jurnal Dialectologia, 22

Jumalia, Jumahir. 2016. "The Genealogi Relationship of Language and Culture of South Halmahera Languages" (Draf Disertasi) Makasar: Faculty of Cultural Science Postgraduate Program of Hasanuddin University

Kamholz, David Christopher. 2014. Austronesians in Papua: Diversification and Change in South Halmahera-West New Guinea. (Disertasi Doctor of Philosophy). Berkeley: University of California

Lewis, M. Paul dkk, ed. 2016. Ethnologue: Languages of the World. 17th edition. Dallas, Texas: Summer Institute of Linguistics, Inc.

Mahsun. 2013. Metode Penelitian Bahasa. (Edisi Revisi). Jakarta: Rajawali Grafindo.

Masinambow, EKM. 1976. Konvergensi Etnolinguistik di Halmahera Tengah: Sebuah Analisa Pendahuluan. Semarang: IKIP Semarang Press 
96 Leksema Vol 4 No 2 Juli-Desember 2019 